\title{
Distinguishing Between Consensual and Nonconsensual Advantages of Liability Rules
}

\author{
Ian Ayres ${ }^{\dagger}$ and Eric Talley ${ }^{\dagger \dagger}$
}

Louis Kaplow and Steven Shavell's thoughtful reply to our recent article contains powerful insights about the relative efficiency of liability and property rules. ${ }^{1}$ While we are in agreement that liability rules can be more efficient than property rules when transaction costs are low, we disagree about the cause of this liability-rule advantage. Kaplow and Shavell believe that liability rules hold only a nonconsensual advantage over property rules (i.e., liability rules tend to induce efficient nonconsensual takings). While granting this oftrecognized nonconsensual advantage, we contend that liability rules may also have a consensual advantage in low-transaction-cost settings (i.e., liability rules facilitate trade). We use this Comment as a forum to articulate our side of the story.

Our answer consists of two parts. In Part I, we locate the current debate within the broader context of entitlement form, transaction costs, and bargaining. In Part II, we provide an example that distinguishes between the consensual and nonconsensual advantages of liability rules.

\section{LOCATING THE DEBATE}

Before plunging into the technical arguments, it may first be helpful to contextualize our initial contribution and its relation to the debate between ourselves and Kaplow and Shavell. In Solomonic Bargaining, we ventured into what we termed "the economic purgatory between the findings of Coase and of Calabresi and Melamed."2 This phrase bears elaboration.

Calabresi and Melamed argued persuasively that, when transaction costs make consensual transfer prohibitively expensive, liability rules are likely to dominate property rules because liability rules more closely replicate the

$\dagger$ William K. Townsend Professor of Law, Yale Law School.

it Assistant Professor, University of Southern California Law Center. Jennifer Brown, Dick Craswell, Ed McCaffery, Jeff Strand, and Chris Sanchirico provided helpful comments.

1. See Louis Kaplow \& Steven Shavell, Do Liability Rules Facilitate Bargaining? A Reply to Ayres and Talley, 105 YALE L.J. 221 (1995). Kaplow and Shavell's reply responds to Ian Ayres \& Eric Talley, Solomonic Bargaining: Dividing a Legal Entitlement To Facilitate Coasean Trade, 104 YALE L.J. 1027 (1995).

2. Ayres \& Talley, supra note 1 , at 1098 . 
outcome that transaction costs preclude. ${ }^{3}$ When transacting is costless, Coase tells us that liability and property rules are equally efficient. ${ }^{4}$

In the last twenty-some years, numerous law-and-economics scholars have attempted to connect the dots between these efficiency benchmarks characterized by Coase, on the one hand, and Calabresi and Melamed, on the other. In this so-called "economic purgatory," transaction costs are positive but not prohibitive. ${ }^{5}$ Richard Posner has characteristically offered a lucid and

3. See Guido Calabresi \& A. Douglas Melamed, Property Rules, Liability Rules and Inalienability: One View of the Cathedral, 85 HARV. L. REV. 1089 (1972). Calabresi and Melamed's account of the nonconsensual (or so-called "Hobbesian") case within jurispnudential categories deserves substantial credit. Under a property rule, nonholders of an entitlement must bargain with holders to effect a transfer of ownership. Under a liability rule, however, one may interfere nonconsensually with the entitlements of another, but must subsequently reimburse the nominal owner with a market-mimicking "price" (also known as damages). Ayres \& Talley, supra note 1, at 1106-10. Kaplow and Shavell, in a separate piece, have placed this insight on a much firmer theoretical ground. See Louis Kaplow \& Steven Shavell, Property Rules Versus Liability Rules (Harvard Law School Program in Law and Economics, Discussion Paper No. 156, Mar. 1995) (forthcoming 109 HARV. L. REV., 1995). They show that, even if damages are set imprecisely, liability rules can induce beneficial nonconsensual taking. As long as the damages are an unbiased estimate of the victim's injury, injurers will cause harm only when their benefits exceed the average harm that they cause. Id. at 17-20. Kaplow and Shavell's insight is important because the current prohibitions against awarding "speculative" damages may be misplaced if we believe that factfinders can generate imprecise, but unbiased, estimates of damages.

In Solomonic Bargaining, we also made an argument for inaccurate or "untailored" liability rules, but one that was different than Kaplow and Shavell's. We stressed that inaccuracy may be even better than accuracy when bargaining is allowed, as it affects the revelation of valuable information. See Ayres \& Talley, supra note 1, at 1065-72. A number of recent papers have noticed this tendency in various other contexts as well. See Jason S. Johnston, Bargaining Under Rules Versus Standards, 11 J.L. ECON. \& ORGANIZATION (forthcoming Oct. 1995) (arguing that bargaining under standards may be more efficient than bargaining under rules); Kathryn Spier, Settlement Bargaining and the Design of Damage Awards, 10 J.L. ECON. \& ORGANIZATION 84 (1994) (arguing that finely tuned damage awards increase probability that litigants will disagree, thereby aggravating settlement process); Eric L. Talley, Contract Renegotiation, Mechanism Design, and the Liquidated Damages Rule, 46 STAN. L. REv. 1195, 1198-99 (1994) [hereinafter Talley, Liquidated Damages] (arguing that nonenforcement of penal liquidated damages clauses can increase economic efficiency by inducing more efficient contract negotiation); Eric L. Talley, Property Rights, Liability Rules, and Coasean Bargaining Under Incomplete Information 26-33 (John M. Olin Program in Law and Economics, Stanford Law School, Working Paper No. 114, Aug. 1994) [hereinafter Talley, Property Rights]. Indeed, Kaplow and Shavell appear to have no quarrel with this point. See Kaplow \& Shavell, supra note 1 , at 222 n.5.

Even though liability rules tend to induce beneficial taking, we will show below that the costs of nonconsensual transfer (e.g., litigation costs) can make property rules more efficient. See infra text accompanying notes $34-35$.

4. This is an implication of the well-known Coase Theorem, which asserts that, so long as parties can contract frictionlessly, efficiency simply happens no matter what form the initial entitlements take. See Ronald H. Coase, The Problem of Social Cost, 3 J.L. \& ECoN. 1 (1960).

5. When friction grows large, however, the Posnerian thesis asserts that the costs of inducing an agreement will become too great, and it would be more prudent to adopt a public-ordering scheme (such as liability rules) to approximate market outcomes. See RICHARD A. POSNER, ECONOMIC ANALYSIS OF LAW 57 (4th ed. 1992). We cite Posner here principally for his clear thesis and summary of the literature. Others, such as A. Mitchell Polinsky, have made substantial contributions to this literature. See A. Mitchell Polinsky, Controlling Extemalities and Protecting Entitlements: Property Right, Liability Rule, and TaxSubsidy Approaches, 8 J. LEGAL STUD. 1 (1979) [hereinafter Polinsky, Controlling Externalities]; A. Mitchell Polinsky, On the Choice Between Property Rules and Liability Rules, 18 ECON. INQUIRY 233 (1980); A. Mitchell Polinsky, Resolving Nuisance Disputes: The Simple Economics of Injunctive and Damage Remedies, 32 STAN. L. REv. 1075 (1980) [hereinafter Polinsky, Resolving Nuisance Disputes]. Posner's theory that property rules are efficient in low transaction costs settings is explicitly based on the claim that property rules tend to "channel ... transactions through the market." POSNER, supra, at 230. While we attribute this thesis to Posner, many academics (including, until recently, ourselves) accepted its 
powerful theory by arguing that, in settings with "low" transaction costs, property rules are more efficient than liability rules because they channel transactions into the market. ${ }^{6}$

Solomonic Bargaining challenged this view in the context of a specific type of transaction cost: private information. ${ }^{7}$ Our core insight was that dividing an entitlement between two negotiators could cause more forthright and efficient bargaining. Essentially, we argued that these so-called Solomonic divisions tend to obscure the titular boundary between "buyer" and "seller" during bargaining and, in so doing, dampen the parties' strategic incentives to "shade up" or "shade down" their privately known valuations. We argued that numerous entitlement divisions can cause this phenomenon, including divisions along use, space, and time dimensions; divided ownership through judicial randomness (i.e., "probabilistic" divisions); and divided ownership through untailored liability rules. ${ }^{9}$

It is with our extended analysis of this last form of division that Kaplow and Shavell find their sole quarrel. They agree with us that liability rules can be more efficient than property rules. ${ }^{10}$ They part company with us, however, in interpreting the cause of this postbargaining advantage. Kaplow and Shavell argue that our analysis of liability rules failed to distinguish between the consensual and nonconsensual attributes of liability rules, and they conjecture that any advantage liability rules possess stems not from bargaining, but rather from the persistence of the Calabresi-Melamed "head start" that liability rules enjoy in the absence of bargaining. ${ }^{11}$ More explicitly, they argue that liability rules have a nonconsensual advantage over property rules when trade is not possible, and that this nonconsensual advantage tends to persist once bargaining is allowed. While Solomonic Bargaining focused on a consensual advantage of liability rules (i.e., that liability rules could facilitate trade), Kaplow and Shavell attribute the efficiency of liability rules in our example

validity. See sources cited in Ayres \& Talley, supra note 1, at 1032-33 nn.17-18.

6. See POSNER, supra note 5, at 57 (noting that "[in settings with low transaction costs] the law should require the parties to transact in the market; it can do this by making the present owner's property right absolute (or nearly so), so that anyone who thinks the property is worth more has to negotiate with the owner"); see also WILLIAM M. LANDES \& RICHARD A. POSNER, THE ECONOMIC STRUCTURE OF TORT LAW 48 (1987) ("The purpose of awarding punitive damages is to direct these transactions into the market, where they belong, because market transaction costs are low in these cases ....").

7. Informational asymmetries represent transaction costs because they often give parties the incentive to misrepresent their private knowledge, thereby retarding, delaying, or even thwarting potentially efficient trades. See Ayres \& Talley, supra note 1, at 1030.

8. The technical term for such phenomena is "countervailing incentives." See id. at $1030 \mathrm{n} .8$ (citing sources).

9. See id. at 1033-35. The exact manner in which liability rules can help to elicit information revelation is restated infra in the text accompanying notes $29-33$.

10. Moreover, Kaplow and Shavell apparently concur with the observations we made concerning other types of entitlement division. See Kaplow \& Shavell, supra note 1, at 222 n.5.

11. See id. at 228-29. Kaplow and Shavell, consistent with this characterization, hypothesize that, as we move closer to the Coasean ideal of zero transaction costs, this head start still persists, but decreases in magnitude. See id. 
to the persistence of a nonconsensual advantage (i.e., that liability rules tend to induce taking by higher valuers). While we agree with Kaplow and Shavell that liability rules enjoy a "head start" in this horse race (before bargaining occurs), we disagree with their conjecture that this head start alone preordains the outcome of the race (after bargaining). Instead, we maintain that bargaining concerns can play an important (and possibly first-order) role in the normative choice between liability and property rules.

A diagram representing the competing views may help flesh out the debate more fully. Figure 1 heuristically depicts the relative efficiency of property rules and liability rules as transaction costs vary between zero and infinity. ${ }^{12}$ The origin of the diagram represents the Coase Theorem benchmark of zero transaction costs. ${ }^{13}$ Here, property and liability rules are indistinguishable from an efficiency standpoint-neither produces any inefficiency. The right side of the diagram corresponds to the other polar extreme, in which transaction costs are infinitely high. Here, there is no bargaining, and Calabresi and Melamed's nonconsensual "head start" of liability rules over property rules frequently prevails. ${ }^{14}$

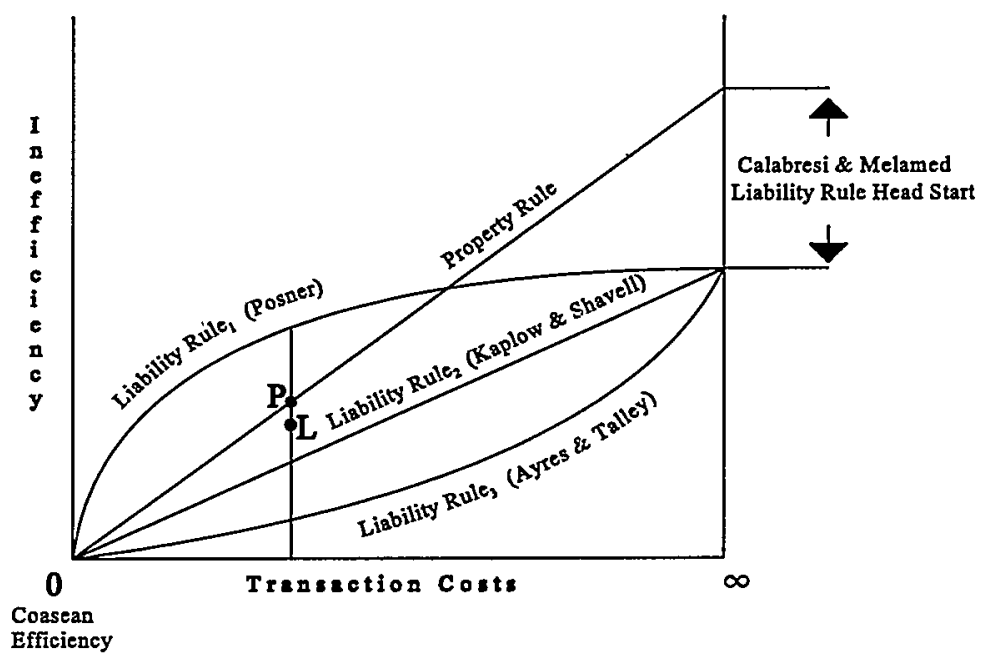

FIGURE 1.

12. At the outset, we stress that there is no natural way to quantify transaction costs, and many types of transaction costs (such as asymmetric information) are difficult to represent on a smooth continuum. See Ayres \& Talley, supra note 1, at 1036 ("[T] he type of transaction cost matters: It is inadequate to think of 'transaction costs' as some sort of composite good whose components imply similar policies."). Nevertheless, Figure 1 is illuminating, and we will refer to it frequently in the pages below.

13. It is somewhat misleading to associate the adjective "Coasean" with zero transaction costs, since Coase spent so much of his career arguing against the assumption of zero transactions costs. See Robert C. Ellickson, The Case for Coase and Against "Coaseanism," 99 YALE L.J. 611 (1989).

14. Liability rules may not have a nonconsensual "head start" if litigation is costly. See infra text accompanying notes $27-28$ and Figure 2. 
Between these two extremes, we can use Figure 1 to distinguish between the competing characterizations of relative efficiency outlined above, which, for convenience, we associate with the names of Posner, Kaplow and Shavell, and ourselves. For the purposes of exposition, we posit a fixed, linear relation between the size of transaction costs and the inefficiency under a property rule ${ }^{15}$-and show what the three theories say about the relative shape of the liability-rule curve.

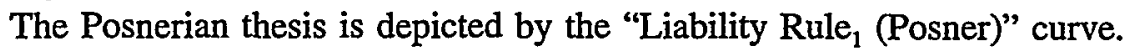
The strictly concave shape of this curve is intended to depict the asserted dominance of property rules in low-friction settings and the eventual point where liability rules overtake property rules as transaction costs grow. ${ }^{16}$ Kaplow and Shavell's argument is depicted by the linear "Liability Rule (Kaplow \& Shavell)" schedule. The linearity of this curve illustrates their "persistence conjecture" in that the relative efficiency at the endpoints of the diagram will tend to dictate the position of the curves in the interior. ${ }^{17}$ Finally, the possibility that we raised in Solomonic Bargaining - that liability rules might facilitate more efficient bargaining - appears as the "Liability Rule ${ }_{3}$ (Ayres \& Talley)" schedule. The convex shape of this curve is intended to depict our assertion that a postbargaining advantage of liability rules might reflect more than the simple preservation of the head start, because liability rules can also work to lubricate consensual transactions between the parties. ${ }^{18}$

It is important to emphasize that these three conceptions of relative efficiency (depicted in Figure 1) also make different claims about the likelihood that a particular advantage will obtain. The Posnerian conception makes the strongest claim: When transaction costs are low, property rules will

15. Because there often is no natural metric for measuring the size of transaction costs, the figure arbitrarily calibrates transaction cost so as to make the property-rule line linear. We might just as easily posit a linear liability rule and show three property-rule lines.

16. If Posner accepts the Calabresi and Melamed thesis that liability rules tend to be efficient when contracting is impossible, then the liability-rule and property-rule curves must intersect at least once. But Posner does not suggest at what level of transaction costs we might expect such a crossover point.

17. The persistence conjecture essentially interpolates between the Coasean ideal and the Calabresi and Melamed head start. Thus, even if this schedule is not linear, their analysis implies linearity as a central tendency. Figure 1 also illuminates how Kaplow and Shavell's persistence theory underlies their two core conjectures about the relative efficiency of liability and property rules when bargaining is possible but imperfect:

First Conjecture: "[T] he liability rule will tend to produce greater total welfare than property rules (but the advantage of the liability rule will be less than when bargaining is impossible)." Kaplow \& Shavell, supra note 1, at 224. This conjecture is depicted in Figure 1 because the "Liability Rule, $_{2}$ schedule is everywhere below the "Property Rule" schedule.

Second Conjecture: "[P]roperty rules will lead to greater bargaining-related welfare gains than does the liability rule."

Id. (emphasis omitted). This conjecture is depicted in Figure 1 because the "Property Rule" line has a steeper slope than the "Liability Rule" line.

18. This "consensual" advantage is not the only reason that liability rules may be more efficient than property rules. Rather, we hypothesize that Solomonic bargaining as well as the nonconsensual head start could make liability rules more efficient. See Ayres \& Talley, supra note 1, at 1059 n.101. 
always be more efficient than liability rules. ${ }^{19}$ Kaplow and Shavell make a more modest claim, that liability rules "tend to be" more efficient. ${ }^{20}$ And, on this likelihood dimension, our thesis is the most modest. We only claim that liability rules might facilitate trade as indicated by "Liability Rule ${ }_{3} .{ }^{.21}$ The goal of Solomonic Bargaining was to provide a "possibility theorem." By showing that liability rules could produce a more efficient equilibrium with more contracting, we refuted the strong-form Posnerian claim that property rules must be more efficient than liability rules when transaction costs are low.

To be sure, we believe that property rules are often efficient, but a primary goal of Solomonic Bargaining was to show that the efficiency of property rules could not be justified by the traditional claims that they are "market encouraging"; liability rules can channel even more transactions into the market and produce a more efficient equilibrium. We developed an example that contradicted the Posnerian thesis in that an untailored liability rule produced larger gains from trade and more contracting than a property rule. ${ }^{22}$

19. Although Posner and like-minded scholars do not use the adverb "always," the unqualified, a priori terms in which the thesis is put at least are susceptible to this interpretation. See supra note 6.

20. Kaplow and Shavell would readily admit that bargaining might make a property rule more efficient than a liability rule (as depicted in Figure 1 by "Liability Rule"). See Kaplow \& Shavell, supra note 1, at 223-24. Indeed, our analysis of tailored liability rules provides just such an example: The tailored liability rule is more efficient when bargaining is not possible, but becomes less efficient when bargaining is possible. The perverse effects of tailoring demonstrate that bargaining can have dominant effects on the relative efficiency of liability and property rules. Kaplow and Shavell offer no reason to suggest why these dominant effects can only run in one direction (why we might have "Liability Rule," but not "Liability

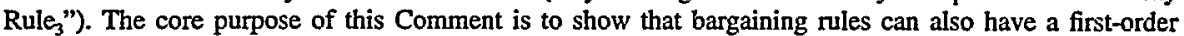
effect in improving the relative efficiency of liability rules.

21. At several points in their comment, Kaplow and Shavell lose sight of this fact. For example, they point to a variation in our bargaining model (where the defendants' valuation can take on any value between $\$ 0$ and $\$ 100$ ) in which a property rule is more efficient than a liability rule. They suggest that in this variation, our "thesis is starkly contradicted." Id. at 231 (emphasis added). Our thesis, however, is not that liability rules must be more efficient. Indeed, like Kaplow and Shavell, we believe that property rules will often be efficient when transaction costs are low (i.e., we believe that a liability rule may induce a curve like "Liability Rule"). Pointing to a variation where proferty rules are more efficient does not starkly contradict our thesis that liability rules might be more efficient.

Likewise, Kaplow and Shavell's repeated use of the phrase "the opposite of their thesis," see, e.g., id. at 222 , is misleading. The opposite of our thesis, that "liability rules might facilitate trade," would be a claim that "liability rules cannot facilitate trade." As we have said in the text, it would be appropriate for them to say that our example does not adequately distinguish our (consensual) information-forcing effect from their (nonconsensual) persistence effect, but it is inappropriate to say that our example showing that a liability rule can produce more trade and higher welfare illustrates "the opposite of their [Ayres and Talley's] thesis."

We are attracted to Kaplow and Shavell's persistence conjecture as a general tendency. See Ayres \& Talley, supra note 1, at 1059-60 n.101. But the strong theoretical rationale behind persistence as a central tendency does not preclude the possibility of the relationships depicted by either "Liability Rule," or "Liability Rule," Indeed, Kaplow and Shavell's belief in persistence does not preclude the possibility that liability rules may perform disproportionately badly when bargaining is allowed. Similarly, the persistence conjecture does not provide any "a priori reasoning" to indicate that liability rules might not perform disproportionately well. Accordingly, Kaplow and Shavell's assertion that "[a] priori reasoning suggests that the opposite of [Ayres \& Talley's] thesis is likely to be true," Kaplow \& Shavell, supra note 1, at 222, does not follow.

22. See Ayres \& Talley, supra note 1, at 1047-61. Posner might claim that the imperfect information in our example did not constitute a "low"-transaction-cost setting. While there is no natural metric for measuring the size of transaction costs, the asymmetric information in our model allowed for a substantial 
This example is illustrated in Figure 1 by points $\mathrm{P}$ and $\mathrm{L}$. The distance between $P$ and the horizontal axis represents the amount of inefficiency that remains after bargaining under a property rule, and the distance between $L$ and this axis represents the analogous amount under a liability rule. Even with the transaction costs in our model (i.e., asymmetric information), we found parties contracting in the shadow of either rule; and after contracting, liability rules were more efficient than property rules (i.e., Point $\mathrm{L}$ is below Point $\mathrm{P}$ ). ${ }^{23}$

Kaplow and Shavell's criticism of this core example can also be described using Figure 1. They agree that we have produced an example that refutes the Posnerian claim that property rules are more efficient when transaction costs are low, but they point out that the efficiency of the liability rule in our example may be due to the persistence of the rule's nonconsensual advantage and not to its ability to facilitate trade (a theoretical difference depicted by the fact that the "Liability Rule 2 " schedule lies between point $L$ and our "Liability Rule $_{3}$ " schedule).

We concede that Kaplow and Shavell are right that our original example did not adequately distinguish between the consensual and nonconsensual advantages of liability rules. ${ }^{24}$ While the example does succeed in refuting the Posnerian hypothesis, our article's focus on what happens as one moves away from the point of Coasean efficiency (i.e., away from the origin in Figure 1) blinded us to the possibility that the liability rule's nonconsensual head start (from the other direction) might persist.

To show that liability rules can facilitate trade in a way that is distinct from the nonconsensual head start, we need to construct an example under which bargaining in the shadow of a liability rule disproportionately mitigates

amount of bargaining: Contracting in the shadow of a liability rule eliminated $75 \%$ of the inefficiency associated with autarky. Moreover, the qualitative efficiency of the liability rule in our example would persist as one collapsed the range of private valuations arbitrarily close to the mean of $\$ 50$, thus coming arbitrarily close to a zero-transaction-costs world.

23. Moreover, in our example there was a $30 \%$ chance that the parties would contract when bargaining in the shadow of a liability rule, but only a $20 \%$ chance that they would contract in the shadow of a property rule-casting additional doubt on the "market-creating" rationale for property rules.

24. We disagree with Kaplow and Shavell, however, about the correct standard for measuring whether bargaining under a liability rule facilitates trade. In terms of Figure 1, Kaplow and Shavell argue that showing liability rules might facilitate trade would require showing that the liability-rule curve had a steeper slope than the property-rule curve (as we move away from the autarky point), while we argue that it would be sufficient for the liability-rule curve to have only a steeper slope than the straight "Liability Rule" ${ }_{2}$ line. See infra note 45 (discussing difference in these two standards). Nevertheless, we provide an example that satisfies both criteria. See infra note 33 (explaining why postbargaining advantage of liability rules may often exist solely because of bargaining concerns).

Kaplow and Shavell's metric, we believe, puts excessive emphasis on the effects of infra-marginal trades while placing too little weight on marginal effects. Adherence to this metric can lead to perverse conclusions. For instance, even if one were able to show that liability rules (in some form) could lead to Pareto-optimal (or "first-best") outcomes, while property rules could not, Kaplow and Shavell's metric might nonetheless dictate that because of the initial starting positions, property rules-and not liability rules-are the ones that "facilitate trade." We submit that a fair metric should not produce such perverse results. As such, the percentage reduction in inefficiency is a more sensible measure. 
the "initial conditions" that prevail in the absence of bargaining. ${ }^{25}$ The next part provides such an example. Explicitly, we demonstrate that, while litigation costs can dampen-and even reverse-the nonconsensual head start that liability rules enjoy over property rules, bargaining in the shadow of litigation costs can enhance the advantages of liability rules over property rules in the face of these costs.

Our central disagreement with Kaplow and Shavell turns on whether the advantage of liability rules stems solely from the persistence effect, or whether the information-forcing effect of liability rules might at times complement the persistence effect. ${ }^{26} \mathrm{Kaplow}$ and Shavell carefully avoid claiming that liability rules cannot facilitate trade; they only claim that we have not adequately shown that they might. The next part attempts to provide a more persuasive example.

\section{LIABILITY RULES CAN FACILITATE MORE EFFICIENT BARGAINING DESPITE A NONCONSENSUAL DISADVANTAGE}

If the advantage of liability rules lies solely in the persistence of their nonconsensual head start, then reducing or reversing this nonconsensual head start should similarly reduce or reverse the performance of the liability rule when bargaining is allowed. For example, Figure 2 depicts a model in which (contrary to Calabresi and Melamed) a liability rule is less efficient than a property rule when high transaction costs preclude bargaining. Kaplow and Shavell's persistence hypothesis would suggest that there is a tendency for the nonconsensual property-rule advantage to persist once bargaining is allowed-so that for lower transaction costs we would expect point $L$ to be

25. The debate between ourselves and Kaplow and Shavell necessarily proceeds by example and counterexample. Kaplow and Shavell critique our use of a "single numerical example" in illustrating our bargaining argument. See Kaplow \& Shavell, supra note 1, at 227.

For readers familiar with informational bargaining literature, however, Kaplow and Shavell's criticism is not a new one. Bargaining models tend to produce a multiplicity of equilibria that are sensitive to initial modeling assumptions. Thus, much of bargaining literature (including Solomonic Bargaining) has tended to focus on possibility claims rather than more general assertions. See DREW FUDENBERG \& JEAN TIROLE, GAME THEORY 398-99 (1992) (noting that the noncooperative bargaining approach has so far failed to "solv[e] the bargaining problem," and that "[t]he theory of bargaining under incomplete information is currently more of a series of examples than a coherent set of results").

In fact, our awareness of these frustrations explains why, in our earlier analysis, we emphasized that the so-called "separation" phenomenon appears to be more robust-because separation is a weakly dominant strategy. See Ayres \& Talley, supra note 1, at 1042-46.

26. In Solomonic Bargaining, we stated:

Kaplow and Shavell have persuasively shown that liability rules already have a "head start" on property rules under autarky because nonconsensual takings will tend to transfer the entitlement to a higher-valuing owner, and that it is not surprising that this liability-rule advantage persists in circumstances when bargaining is possible. While Kaplow and Shavell are clearly correct about the autarkic headstart of liability rules, the information-forcing property of liability rules may provide an independent reason that liability rules can dominate property rules when bargaining is possible.

Ayres \& Talley, supra note 1, at 1059 n.101 (citation omitted). 
above point $\mathrm{P}$. At the very least, if we could show that such a liability rule became more efficient than a property rule when bargaining was possible (depicted by the possibility that a point $L^{\prime}$ exists below point $P$ ), then we could say with confidence that the liability rule's efficiency does not derive from the persistence of a nonconsensual advantage-in this example there is none-but must come from the beneficial effects of trade.

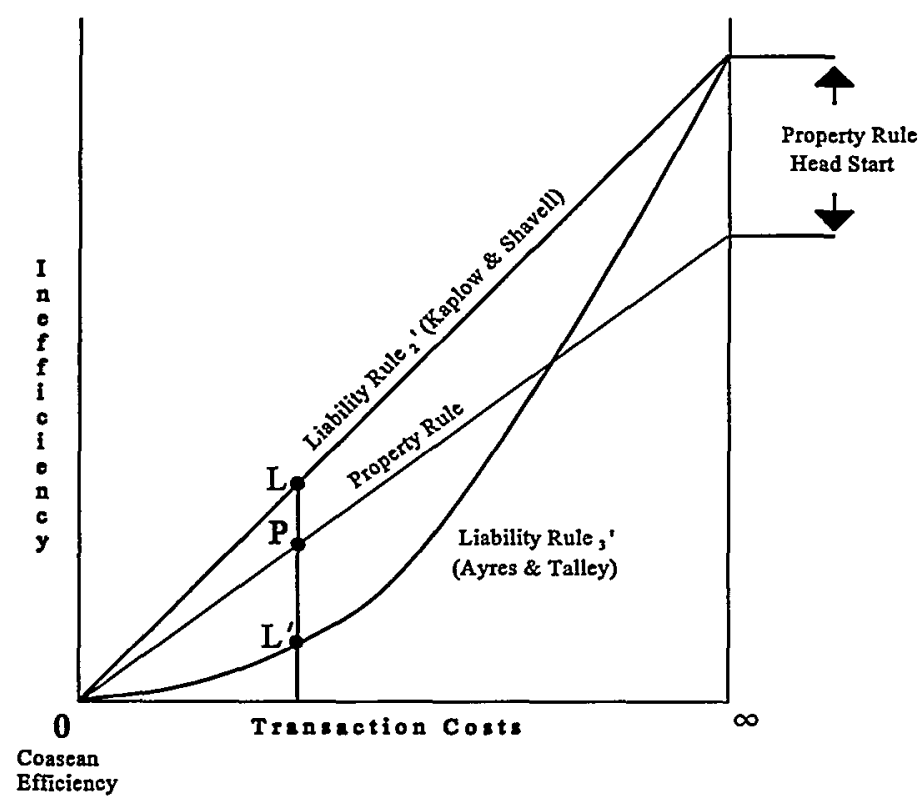

FIGURE 2.

A number of factors might cause liability rules to be less efficient than property rules when bargaining is impossible. In fact, Kaplow and Shavell themselves argue that liability rules may be imprudent if nonconsensual transfer generates various "administrative costs"-including the cost of litigation itself. ${ }^{27}$ We will demonstrate, using a close variation on the model from our earlier article, how the presence of litigation costs can make liability rules less efficient than property rules when bargaining is not possible, yet increase the efficiency advantage of liability rules when bargaining is possible.

To keep things simple, we will stick with the same liability-rule example we used in Solomonic Bargaining, but we will add litigation costs of (slightly less than) $\$ 10$ that each party must pay if litigation arises after a nonconsensual taking. ${ }^{28}$ As before, we assume the defendant's valuation can

27. See Kaplow \& Shavell, supra note 3, at $40-42$.

28. We have assumed that litigation costs are "slightly less than" $\$ 10$ to make clear that a $\$ 60$ defendant would have an incentive to take in the absence of bargaining (we could have achieved the same result by making damages slightly less than $\$ 50$ ). If the $\$ 60$ defendant's litigation costs were $\$ 10$, she would be indifferent between taking nonconsensually and not taking (because the net payoff in either case 
be either $\$ 40$ or $\$ 60$ with equal probability, and the plaintiff's valuation can take on any value between $\$ 0$ and $\$ 100$ with equal probability.

By way of review, let us first quickly summarize the salient features of the equilibrium of our initial game ${ }^{29}$ without litigation costs: ${ }^{30}$

- Plaintiff "partitioning": In the signaling stage, the plaintiffs found it (weakly) dominant to separate themselves into two groups: (1) those whose valuation was less than the damages amount signaled an interest in selling their entitlement; and (2) those whose valuation exceeded damages signaled an interest in purchasing the defendant's right to take. ${ }^{31}$

- Offers: At the offering stage, a defendant hearing a plaintiff's preference for selling will offer $\$ 32.50$ (regardless of the defendant's private valuation), which will be accepted by all plaintiffs who value their entitlements at less than $\$ 15$. Conversely, a defendant hearing a plaintiff's preference for buying will demand $\$ 17.50$ (again regardless of type), which will be accepted by all plaintiffs who value their entitlements at more than $\$ 85^{32}$

- Outcome: After bargaining, the plaintiff property rule yields expected social welfare of $\$ 59.75$, while the liability rule set at $\$ 50$ yields expected social welfare of $\$ 59.88 .^{33}$

will be zero). Taking nonconsensually (in the absence of agreement) would still represent a plausible equilibrium because a $\$ 60$ defendant would not have an affirmative incentive to deviate from this course of action. Assuming litigation costs to be slightly less than $\$ 10$ breaks this indifference, leading a $\$ 60$ defendant to take nonconsensually in the absence of agreement.

29. This game is formally defined in our earlier article. See Ayres \& Talley, supra note 1, at 1048-50. Essentially, the extensive form of this game calls for the plaintiff first to signal whether she wishes to sell her entitlement or buy the defendant's option to take. After the plaintiff sends this signal, the defendant makes a take-it-or-leave-it offer. If the plaintiff rejects the offer, the defendant chooses whether to take nonconsensually and pay the untailored damage amount.

30. See id. at 1050 n.77.

31. Kaplow and Shavell argue that prior writing on bargaining "t[ook] for granted" this separation effect. See Kaplow \& Shavell, supra note 1, at 226 n.17. They cite an unpublished and uncirculated paper in support of this claim. See Steven Shavell, Property Rights and the Rule of Liability in a Simple Bargaining Model (1988) (unpublished manuscript, on file with authors). In this paper, the author appears to recognize implicitly the separation effect, but stresses neither its weakly dominant nature, nor its gametheoretic generality outside of his model. This is not surprising, as the Shavell model does not involve the type of preoffer signaling we discuss in ours.

In the variation we present below, weakly dominant plaintiff partitioning occurs as well, but with a few caveats. See infra text accompanying notes $36-44$.

32. Kaplow and Shavell correctly note that this "pooling" behavior among defendants can be detrimental to the bargaining process. We articulated this potential drawback in our original article. See Ayres \& Talley, supra note 1, at 1055-56. As we demonstrate below, however, defendant pooling need not always dominate. See infra text accompanying notes $42-44$ (illustrating how, in litigation-costs example, half of problem with defendant pooling disappears).

33. In making their criticisms, Kaplow and Shavell use these numbers in comparison to the "no bargaining" outcomes ( $\$ 50$ and $\$ 55$, respectively) to suggest that it is property rules, and not liability rules, that facilitate trade. As mentioned above, we disagree with Kaplow and Shavell about the correct standard for measuring whether liability rules facilitate trade. See supra note 24 . Moreover, examining various other damages amounts between $\$ 40$ and $\$ 60$ may provide reasons to believe that, in our original analysis, the postbargaining advantage of liability rules over property rules is due entirely to bargaining. The rationale for this argument is as follows: In the absence of bargaining, all such intermediate damages amounts 
Adding litigation costs to our previous model eliminates the nonconsensual advantage of liability rules. Litigation costs do not affect the property-rule equilibrium because the defendant would never attempt to take from the plaintiff nonconsensually. Consequently, the property rule's level of expected social welfare absent bargaining remains at $\$ 50$. Under a $\$ 50$ liability rule, it remains the case that when bargaining is not possible only $\$ 60$ defendants will take nonconsensually ${ }^{34}$ But because of the costs of litigation, the aggregate prebargaining expected welfare under a liability rule will be only approximately $\$ 45$, which falls $\$ 5$ short of the analogous measure under a property rule. ${ }^{35}$ As one might expect, the introduction of litigation costs introduces a cost to nonconsensual transactions, and, in fact, it inverts the liability-rule head start under autarky. This possibility is depicted in Figure 2 by the fact that the liability-rule line is above the property-rule line at the point where transaction costs are infinite.

When contracting is costless, of course both liability rules and property rules will engender efficient contracting and maximal efficiency. This again is a direct consequence of the Coase Theorem. In this model, both rules would give rise to an expected surplus of $\$ 63$. The Kaplow-Shavell persistence conjecture would (as we read it) predict that liability rules should now perform uniformly worse when bargaining is possible but imperfect. This is the consequence of simply interpolating between the two "no-bargaining" points and the single point of Coasean efficiency.

perform equally well (producing identical expected social welfare outcomes of $\$ 55$ ), while damages amounts outside this range perform the same as a property nule (expected welfare of $\$ 50$ ). Given this $\$ 5$ head start within the $[\$ 40, \$ 60]$ interval, the "persistence" hypothesis of Kaplow and Shavell suggests that we should see a discontinuous jump in postbargaining welfare as we move from a damages amount just outside this interval to one just inside it. We find no such jump; in fact, the postbargaining welfare curve is continuous at both $\$ 40$ and $\$ 60$. See Ayres \& Talley, supra note 1 , at 1113 (fig. A2). This may suggest that (at least for this specification of the model) the initial "head start" of liability rules as such is irrelevant when one allows bargaining. Further, within this interior damages region, the welfare curve is parabolic, and thus there is a unique postbargaining level of damages (i.e., \$50) that maximizes expected social welfare. Id. This parabolic shape is not implied by the "prebargaining" analysis, and therefore, we submit, is due entirely to bargaining. For it is the $\$ 50$ liability rule that gives rise to the maximum amount of plaintiff partitioning.

Kaplow and Shavell might respond to this point by asserting that the level of damages near the boundary of this interior region functions just like a property rule. See Kaplow \& Shavell, supra note 3, at 34 n.64. Such a retort, however, does not follow from, and is in fact inconsistent with, their persistence conjecture. Indeed, absent bargaining there is literally no welfare difference between any of the damages amounts on the $[\$ 40, \$ 60]$ interval.

34. Taking nonconsensually gives a $\$ 60$ defendant a payoff slightly greater than zero, because its litigation costs will be slightly less than $\$ 10$ and it will have to pay $\$ 50$ in damages, while choosing not to take generates a zero payoff.

35. Half the time (when there is a $\$ 40$ defendant) there will be no taking, and the expected welfare will be the plaintiff average value of $\$ 50$. Half the time (when there is a $\$ 60$ defendant), there will be a taking, and the expected welfare will be the defendant's $\$ 60$ value minus approximately $\$ 20$ in litigation costs. Thus, the aggregate expected welfare for a $\$ 50$ liability rule when bargaining is not possible is .5 $(\$ 50)+.5(\$ 60-\$ 20)=\$ 45$. 


\section{A. Deriving the Equilibrium Bargaining Strategies}

Kaplow and Shavell's prediction, however, is not borne out in this example. Using the same extensive-form bargaining game we analyzed in Solomonic Bargaining, it is possible to compare a property rule to a liability rule with respect to their abilities to engender efficient bargaining. First, consider bargaining in the shadow of a property rule. This is the easier case to consider, because the equilibrium is unaffected by the introduction of litigation costs. Regardless of the level of litigation costs, defendants facing a property rule will never attempt to take nonconsensually, and thus litigation costs will not affect the parties' bargaining behavior. As before, all plaintiffs will signal a willingness to sell their entitlement. The $\$ 40$ and $\$ 60$ defendants will bid $\$ 20$ and $\$ 30$, respectively, and these bids will be accepted by any plaintiffs who value their entitlements less than the bids. This bargaining under a property rule increases expected social welfare from $\$ 50$ to $\$ 59.75$.

Under an untailored $\$ 50$ liability rule, however, we find that litigation costs do change bargaining behavior. Specifically, we find that the following constitutes an equilibrium to the game:

(1) The plaintiff signals a willingness to sell her entitlement whenever her valuation is less than $\$ 70$, and a willingness to buy the defendant's option when her valuation exceeds $\$ 70$.

(2) If the plaintiff signals that she wishes to purchase the defendant's option, both $\$ 40$ and $\$ 60$ defendants ask $\$ 15$, and plaintiffs valuing their entitlements more than $\$ 70$ accept these offers.

(3) If the plaintiff signals that she wishes to sell her entitlement, the $\$ 40$ defendant will offer $\$ 20$, and the $\$ 60$ defendant will offer (slightly more than) $\$ 40 .{ }^{36}$ Plaintiffs valuing their entitlements less than $\$ 20$ will accept the $\$ 20$ offer, and all plaintiffs will accept the $\$ 60$ defendant's offer.

To understand why this is an equilibrium, consider each of the parts (1)-(3). First, the $\$ 50$ liability rule induces plaintiffs to partition themselves into "greater than $\$ 70$ " and "less than $\$ 70$ " sets, because $\$ 70$ is the amount that equalizes each plaintiff's payoff from buying the defendant's option or selling her own entitlement. ${ }^{37}$ Introducing litigation costs alters our assertion that "[u]nder liability rule protection... only plaintiffs who value the entitlement less than the damage amount would have an incentive to express

36. As described infra note 44 , if the litigation costs are slightly less than $\$ 10$, then an arbitrarily small proportion of $\$ 60$ defendants will attempt to pool with the $\$ 40$ defendants by offering $\$ 20$.

37. A $\$ 70$ plaintiff signaling a willingness to buy defendant's option would expect in equilibrium (as specified in (2)) to pay $\$ 15$ and would have a net payoff of $\$ 55(\$ 70-\$ 15)$. A $\$ 70$ plaintiff signaling a willingness to sell her own entitlement would expect (as specified in (3)) to sell for (slightly more than) $\$ 40$ half the time and to reject a $\$ 20$ offer half the time-thus also yielding an expected payoff of $\$ 55(.5$ $(\$ 70)+.5(\$ 40))$. 
interest in selling their entitlement. ${ }^{338}$ In this example, the point of division occurs at a point substantially higher than the liability amount. The partitioning point shifts because litigation costs introduce an additional motivation for a plaintiff with an intermediate valuation to sell. In the original model (without litigation costs), we noted:

A number of plaintiffs with intermediate valuations ... will be indifferent between expressing interest in the two types of Coasean trade, because these plaintiffs know that in equilibrium they will not be able to reach agreement with defendants exploiting their take-it-orleave-it power. The valuation of these plaintiffs is not sufficiently different from the damage amount to make trade worthwhile... Thus, in many real-world settings, we would expect plaintiffs to partition themselves into three groups: High valuers would seek to bribe defendants, low valuers would seek to be bribed, and intermediate valuers would remain silent. ${ }^{39}$

But once we add litigation costs to the model, plaintiffs with intermediate values are no longer indifferent; they may be able to capture a small share of the bargaining surplus that is created if they consensually transfer their entitlement to $\$ 60$ defendants without incurring litigation costs. The reason to sell to these $\$ 60$ defendants is not to change the identity of the ultimate owner (because the $\$ 60$ defendant would take in the absence of trade) but to effect the transfer in a less expensive way. The possibility of capturing a small share of this new type of bargaining surplus leads some intermediate-value plaintiffs (who previously were indifferent) to signal a desire to sell. Thus, because a plaintiff with a valuation of $\$ 51$ knows that she cannot profitably bribe a $\$ 60$ defendant not to take ${ }^{40}$ she has an incentive to express interest in selling her entitlement to avoid the litigation costs. ${ }^{41}$

The liability rule still has an information-forcing effect on plaintiffs. The high-value and low-value plaintiffs still seek contracts to change the identity of the ultimate owner: High-value plaintiffs attempt to deter inefficient transfer,

38. Ayres \& Talley, supra note 1 , at 1044.

39. Id. at $1053 \mathrm{n} .89$.

40. Defendants in this model who are allowed to make a take-it-or-leave-it offer will find it profitable to demand a large enough bribe that the plaintiff could earn more by selling.

41. Indeed, the defendant's offer to buy represents a unique trembling-hand equilibrium; that is, it would survive the introduction of "trembles" into the defendant's offering strategy. As explained below, within this class of Coasean transaction, $\$ 40$ and $\$ 60$ defendants will separate completely (or almost so), so that the $\$ 60$ defendants will make revealing litigation-cost-saving offers. It is optimal for a $\$ 60$ defendant to make such an offer so as to give the plaintiff the minimum gain from bargaining, and thus the $\$ 60$ defendant will offer an amount just equal to the plaintiff's net payoff after a nonconsensual taking or to the difference between the damages amount and litigation costs (which is $\$ 40$ ). Knowing this, a certain range of plaintiffs may be indifferent between soliciting bids and offers from defendants. Nonetheless, if we were to "tremble" the high-valuing defendant's offer infinitesimally above $\$ 40$, it would give all these indifferent plaintiffs an incentive to partition themselves along the lines delineated in the text. For more on such so-called "trembling hand" equilibrium refinements, see JEAN TIROLE, THE THEORY OF INDUSTRIAL ORGANIZATION 445-46 (1988). 
and low-value plaintiffs attempt to induce efficient transfer. Indeed, the introduction of litigation costs enhances the information-forcing effect as the lower cutoff for high-value plaintiffs drops from $\$ 85$ to $\$ 70$ and the upper cutoff for low-value plaintiffs rises from $\$ 15$ to $\$ 20$. Essentially, the introduction of litigation costs eliminates the indifference of intermediatevaluing plaintiffs who, in the absence of litigation costs, knew they were not destined to contract regardless of their signal. These plaintiffs now have an incentive to signal a desire to sell their entitlement: the desire to avoid litigation costs.

Let us turn now to part (2), to wit: If the plaintiff signals that she wishes to purchase the defendant's option, both the $\$ 40$ and $\$ 60$ defendants pool in issuing an asking price of $\$ 15$. Any plaintiff valuing more than $\$ 70$ will in fact accept this offer. Note that the imposition of litigation costs will tend to lower the pooled asking price (from $\$ 17.50$ in our original Article to $\$ 15$ now), and increase the range of accepting plaintiffs (from $\$ 85$ and up before to $\$ 70$ and up now). This increase in efficiency-enhancing transactions is due to both parties' wishes to avoid losing litigation costs from nonconsensual takings. Because the threat of litigation costs increases the marginal costs of bargaining breakdown, the defendant will not attempt to extract as much from the plaintiff, and the plaintiff will be more willing to accept the defendant's offer.

Conversely, if the plaintiff signals that she wishes to sell her entitlement, as described in part (3), $\$ 60$ defendants will bid infinitesimally more than the plaintiff's net gain from taking-that is, slightly more than $\$ 40 .{ }^{42}$ The plaintiff will know that this bid must have come from a high-valuing defendant. ${ }^{43}$ Nonetheless, the plaintiff will accept this bid, since she knows it is marginally more than she might expect if the defendant were forced to litigate.

The exposed $\$ 40$ defendant, on the other hand, will offer $\$ 20$ to buy from the plaintiff, and the plaintiff will accept only if her valuation is less than $\$ 20 .^{44}$

42. Because litigation costs $\left(\varepsilon_{L}\right)$ are slightly less than $\$ 10$, the plaintiff's net payoff from a nonconsensual taking would be $\$ 50-\left(\$ 10-\varepsilon_{\mathcal{L}}\right)$, which simplifies to $\$ 40+\varepsilon_{L}$. It is an equilibrium of the model for $\$ 60$ defendants to offer to buy for $\$ 40+\varepsilon_{L}$, and for all plaintiffs with valuations less than $\$ 70$ to accept. The $\$ 60$ defendant's strategic choice is more difficult. She now has two options in making her bid. First, the $\$ 60$ defendant can attempt to pool her bid with that of the $\$ 40$ defendant, as was the case in the zero-litigation-costs model. Second, however, the high-valuing defendant might consider making a bid that reveals her valuation to the plaintiff but makes the plaintiff marginally better off than if the defendant had simply decided to take nonconsensually. When litigation costs are $\$ 10$ for each party, this type of "separating" equilibrium is exactly what we find.

43. A $\$ 40$ defendant would never bid more than $\$ 40$ for the plaintiff's entitlement.

44. A few notes on varying the litigation-cost parameter are in order. When litigation costs exceed $\$ 50$, it is common knowledge that the plaintiff will never bring suit, and thus a liability rule effects a de facto prodefendant property rule. When litigation costs are between $\$ 10$ and $\$ 50$, it is common knowledge that the plaintiff will bring suit, and as such, that the defendant does not pose a credible threat to take. See Talley, Liquidated Damages, supra note 3, at 1233-35. In this instance, a liability rule effectively imposes a proplaintiff property rule. 
B. Liability Rules Can Facilitate a More Efficient Equilibrium-Even When There Is No Nonconsensual Advantage

This litigation-cost model more clearly distinguishes the consensual and nonconsensual advantages of liability rules. Even though in this model the liability rule is less efficient than the property rule when bargaining is not allowed, the liability rule becomes more efficient than the property rule when bargaining is allowed. In other words, even when the liability rule does not have a nonconsensual head start, it can still be more efficient because of a consensual advantage. Even though litigation costs impose a nonconsensual "friction" (which, absent bargaining, makes the liability rule less attractive than a property rule), the liability rule's ability to facilitate bargaining more than makes up for the property rule's head start.

\begin{tabular}{|l|c|c|c|}
\hline & $\begin{array}{c}\text { WELFARE: } \\
\text { No BARGAINING }\end{array}$ & $\begin{array}{c}\text { WeLFARE: } \\
\text { BARGAINING }\end{array}$ & $\begin{array}{c}\text { INCREASE IN WELFARE } \\
\text { DUE TO BARGAINING }\end{array}$ \\
\hline PROPERTY RULE & $\$ 50.00$ & $\$ 59.75$ & $\$ 9.75$ \\
\hline LIABILTTY RULE & $\$ 45.00$ & $\$ 61.75$ & $\$ 16.75$ \\
\hline
\end{tabular}

TABLE 1. Applying Kaplow and Shavell's Welfare Analysis to the Litigation-Cost Model

Table 1 applies Kaplow and Shavell's own analysis to the litigation-cost model. While bargaining under a property rule increases welfare by $\$ 9.75$, bargaining under the liability rule induces an increase of $\$ 16.75$. Using Kaplow and Shavell's own criterion, ${ }^{45}$ the "increase in welfare due to bargaining" is

When damages are less than $\$ 10$, the $\$ 40$ and $\$ 60$ defendants do not completely separate (after hearing that the plaintiff wants to sell her entitlement). Instead, the $\$ 60$ defendant plays a mixed strategy where it pools with the $\$ 40$ defendant's bid with probability $\alpha$ and separates (by making the revealing $\$ 40$ bid) with probability $1-\alpha$, where:

$$
\alpha=\frac{(40-4 C)}{(D-40+3 C)}
$$

$D=$ the damages amount, and $C$ is the litigation cost born by each party. So in our example if $C=9.99$ and $D=50$, the probability that a $\$ 60$ defendant will pool is only about a tenth of one percent.

45. Requiring liability rules to produce larger absolute reductions in inefficiency is an overly stringent criterion for determining whether liability rules facilitate trade because this criterion does not take account of the ceiling created by first-best (Coasean) efficiency. To see this, consider again the original example in Solomonic Bargaining, in which, under a liability rule, bargaining raised welfare by $\$ 4.875$ (from $\$ 55$ to $\$ 59.875$ ). Counterfactually, if a liability rule had been able to facilitate first-best efficiency, welfare would have risen by $\$ 8$ (from $\$ 55$ to $\$ 63$ ) because, under our assumptions about the plaintiff and defendant valuation, $\$ 63$ represents the first-best. But under Kaplow and Shavell's absolute increment criterion, even inducing first-best trade would not mean that the liability rule had succeeded in facilitating trade, because the absolute increment bargaining that increased welfare under a property rule was $\$ 9.75$-which would still be more than the $\$ 8$ increment for this hypothetical liability rule. 
greater with the liability rule than with the property rule. This by itself suggests that we have succeeded in providing a numerical example (depicted graphically in Figure 2) in which liability rules facilitate trade.

Perhaps more important, however, is the fact that the introduction of litigation costs makes the liability rule even more efficient than when there are no litigation costs. Bargaining under a liability rule does not merely recapture the $\$ 10$ inefficiency created by litigation costs in autarky $;^{46}$ it in fact increases the expected social welfare under a liability rule from $\$ 59.88$ without litigation costs to $\$ 61.75$ with these costs.

As shown in Figure 3, litigation costs have divergent effects on consensual and nonconsensual inefficiency. Litigation costs increase the nonconsensual inefficiency of the liability rule by $\$ 10$ (as represented by the change from point $\mathbf{N}$ to point $\mathbf{N}^{\prime}$ ). However, allowing bargaining under the liability rule not only avoids litigation costs, ${ }^{47}$ but also channels a wider class of plaintiffs to engage in welfare-enhancing trade by selling their option to take nonconsensually (as represented by the change from $L$ to $L^{\prime}$ ). Even if we ignore the negative impact of litigation costs on the liability rule's efficiency in autarky (thus assuming counterfactually that a liability rule produces the point- $\mathrm{N}$ inefficiency of $\$ 8$ ), bargaining under a liability rule vitiates a larger fraction of the initial inefficiency $(84.375 \%)$ than does bargaining under a property rule (75\%). Figure 3 depicts this result by the fact that L' lies below Kaplow and Shavell's original "Liability Rule" ${ }_{2}$ line.

Litigation costs make liability rules more efficient in this example because they enhance the partitioning effect that we emphasized in Solomonic Bargaining. Under the liability rule, litigation costs induce even more valueenhancing trade. ${ }^{48}$

Comparing the proportional reductions in inefficiency-rather than the absolute reductions-is a superior criterion for distinguishing between consensual and nonconsensual advantages, see Kaplow \& Shavell, supra note 1 , at 228 n.25, because liability rules only "facilitate trade" if they can disproportionately eliminate the autarkic inefficiency. We relate these two standards to Figure 1 , supra note 24.

46. Without litigation costs, a liability rule under autarky produced expected welfare of $\$ 55$; with litigation costs, the expected welfare is only $\$ 45$.

47. In our equilibrium, no litigation occurs, because all $\$ 60$ defendants agree either to buy the entitlement or to sell their option to take.

48. In this litigation-cost model, liability rules also induce more contracting than property rules-indeed, three times as many people will reach agreement under a liability rule than under a property rule. In their original working paper critiquing Solomonic Bargaining, however, Kaplow and Shavell questioned the normative importance of this type of result: "[F]ully half of the agreements concluded under liability rules produce no increase in welfare because these agreements do not alter outcomes; rather these agreements are pure extortions." Louis Kaplow \& Steven Shavell, Do Liability Rules Facilitate Bargaining? A Reply to Ayres and Talley 9-10 (Harvard Law School Program in Law and Economics, Discussion Paper No. 159, Apr. 1995). Kaplow and Shavell are right that, in equilibrium, half of the agreements are between parties who would not behave differently in the absence of agreement, but they fail to mention that half of the "pure extortions" come from $\$ 60$ defendants who agree to buy the plaintiff's entitlement for $\$ 17.50$ when they would have been willing to take nonconsensually and pay damages of $\$ 50$. What might as easily be characterized as "consumer surplus" becomes "pure extortions" in their eyes. 


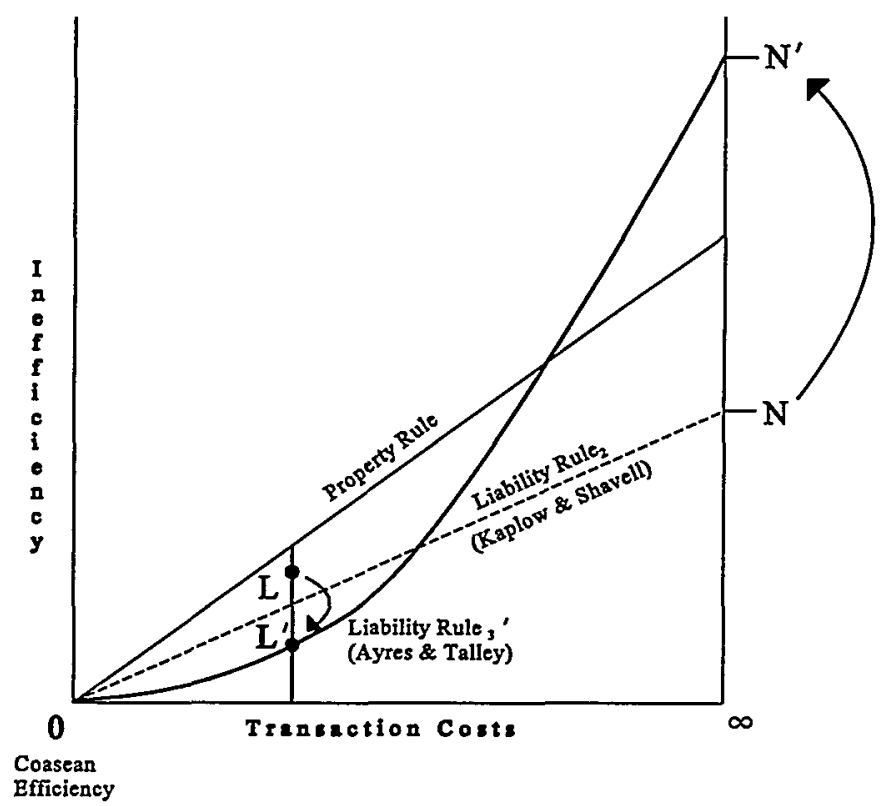

FIGURE 3.

Even if we restrict ourselves to the Kaplow and Shavell standard, liability rules in the textual example can induce more "agreements that increase welfare" than property rules. With litigation costs, a liability rule induces $60 \%$ of the bargainers to reach agreements that increase welfare (while a property rule induces only $25 \%$ ). This $60 \%$ is composed of:

(1) high-value plaintiffs who will successfully deter inefficient taking by $\$ 60$ defendants (15\% of total bargainers);

(2) low-value plaintiffs who will successfully sell their entitlement to $\$ 40$ defendants, who inefficiently would have failed to take ( $10 \%$ of total bargainers); and

(3) mid-range plaintiffs who will sell their entitlement to $\$ 60$ defendants to deter nonconsensual takings that would have consumed $\$ 20$ in litigation costs (35\% of total bargainers).

Thus, litigation costs increase the absolute efficiency of liability rules for two reasons. First, more high-value plaintiffs succeed in deterring $\$ 60$ defendants from inefficiently taking: Without litigation costs, only plaintiffs with valuations greater than $\$ 85$ succeed in bribing; with litigation costs, plaintiffs with valuations above $\$ 70$ deter these inefficient takings. Second, more low-valuing plaintiffs succeed in selling their entitlement to $\$ 40$ defendants: Without litigation costs, only plaintiffs with valuations below $\$ 15$ sell to $\$ 40$ defendants; with litigation costs, plaintiffs with valuations up to $\$ 20$ succeed in this efficient transfer.

If the government knows the distribution of plaintiff and defendant valuations, it might be able to choose the damage amount that maximized expected welfare. But in the absence of this information about underlying valuations, observing the proportion of bargainers who reach agreement might provide some valuable information about where to set the damage rule. Indeed, while far from a general result, in the litigation-cost model the liability rule that maximizes the amount of contracting also maximizes the expected payofis. The notion is that the parties' revealed preference for agreement provides some solace that goods are traveling toward higher-valuing users. After all, if transacting were costless, we might expect to see a large proportion of bargainers entering into some type of transaction. Many scholars have erred in thinking that property rules are necessarily more "market encouraging" than liability rules, but the idea of using revealed preferences in contracting as a crude proxy for efficiency suggests that our finding that $75 \%$ of bargainers reach agreement under a liability rule while only $25 \%$ reach agreement under a property rule would by itself provide prima facie evidence of the liability rule's efficiency. 


\section{CONCLUSION}

Kaplow and Shavell have derived a firmer foundation for the Calabresi and Melamed head start, and they have argued persuasively that this nonconsensual advantage of liability rules will tend to persist once trade is allowed. They were right to challenge us to differentiate more clearly between this nonconsensual advantage and our proposed consensual advantage-that the information-forcing effect of liability rules could facilitate trade. By incorporating litigation costs into our original model, we have done just this-showing that liability rules may induce more efficient postbargaining outcomes even when no nonconsensual advantage exists. If we had needed to make some unnatural assumption to generate this result, we might be justly accused of "theory mining." 49 But our new example, by incorporating litigation costs, moves us, if anything, closer to the real world.

In closing, let us focus on points of agreement. The a priori assertion that property rules are efficient when transaction costs are low, because property rules force people to contract, needs to be qualified. We have shown that liability rules can be more efficient when imperfect information is the only transaction cost and that liability rules can induce more people to contract than property rules.

Kaplow and Shavell's persistence conjecture describes a powerful tendency, but property rules still will often be efficient despite the nonconsensual advantage of liability rules; in this Comment, we have demonstrated that liability rules can still be efficient even when property rules hold a nonconsensual advantage. We believe that this new example demonstrates that "information forcing" can cause liability rules to be more efficient than property rules.

Our disagreement with Kaplow and Shavell about what causes liability rules at times to be more efficient than property rules threatens to obscure the bottom-line policy question of identifying when liability rules are likely to be more efficient than property rules. Distinguishing between the consensual and nonconsensual causes of efficiency can aid in the ultimate inquiry by allowing us to identify circumstances that enhance or retard a particular cause. ${ }^{50}$

49. "Theory mining" is a neologism that refers to how theorists might contrive assumptions to generate a pathological result. (It is analogous to "data mining" in econometrics.) A consequence of theory mining is that, when the parameters are changed only slightly, the result goes away. In fact, in a more formal context of incomplete information, Talley has shown that a large set of litigation costs, so long as they do not destroy the credibility of threats to take or sue, can even lead to first-best outcomes under bargaining (so called ex post efficiency), where property rules are incapable of inducing such bargaining advantages. See generally Talley, Property Rights, supra note 3.

50. For example, we argue that liability rules are less likely to facilitate consensual trade if (1) the liability-rule damages are tailored, see Ayres \& Talley, supra note 1, at 1065 , or (2) the private information of the plaintiff is not the predominant impediment to efficient trade, see id. at 1047. 
Bargaining under imperfect information often leads to complex and subtle equilibria. ${ }^{51}$ Given the richness of these equilibria, it should not be surprising that the information-forcing effect of untailored liability rules might give rise to nontrivial efficiencies. Indeed, our treatment of liability rules represented only a part of our argument in Solomonic Bargaining. Any type of entitlement division $^{52}$ necessarily creates the possibility for two types of Coasean trade: A bargainer can either sell her share of the entitlement or buy the other side's. Our larger thesis remains that bargaining in the shadow of these two types of agreements can induce bargainers to speak more forthrightly and thereby facilitate Coasean trade.

51. See generally Ian Ayres \& Rob Gertner, Strategic Contractual Inefficiency and the Optimal Choice of Legal Rules, 101 YALE L.J. 729 (1992)

52. Solomonic Bargaining discussed a wide array of such divisions including probabilistic, physical, temporal, or activity-level divisions, as well as the way that liability rules divide an entitlement by making ownership subject to a takings option. See Ayres \& Talley, supra note 1, at 1034-35 \& n.24. 
